\title{
DISTRIBUTION, TYPOLOGY AND STRUCTURE OF MICROBIAL MAT COMMUNITIES IN SPAIN: A PRELIMINARY STUDY
}

\author{
I. Esteve ${ }^{1}$, M. Martínez-Alonso ${ }^{1}$, J. Mir $^{1}$ and R. Guerrero2 \\ 1 Department of Genetic and Microbiology and Institute for Fundamental. Biology. Autonomous University of Barcelona, \\ Bellaterra, Spain. \\ 2 Department of Microbiology, University of Barcelona, Spain.
}

Keywords: Microbial mats, Cyanobacteria, Purple sulfur bacteria, Chlorophyll $a$, Bacteriochlorophyll $a$.

\begin{abstract}
This work includes a preliminary study of some microbial mats located in the Mediterranean region of the Iberian Peninsula. The structure of these laminated communities has been studied through the combined use of light microscopy, scanning electron microscopy and pigment analysis.

All the mats studied were made up predominantly of cyanobacteria, with chlorophyll $a$ as the main photosynthetic pigment. Coccoid cyanobacteria were the main organisms in mats with higher salinities. When salinity levels decreased, filamentous cyanobacteria became the principal mat-building organisms. In young mats, Spirulina was dominant, while in well developed mats, where Microcoleus was dominant, a purple layer with bacteriochlorophyll $a$ was also present.
\end{abstract}

\section{INTRODUCTION}

It was more than a century and a half ago that stromatolites were first described (STEEL, 1825). These structures, defined as "organosedimentary structures produced by sediment trapping, binding, and/or precipitation as a result of the growth and metabolic activity of microorganisms, primarily by cyanobacteria" (MARGULIS et al., 1986), are fundamental for a better understanding of microbial mats.

Microbial mats have been described as stratified communities of microorganisms that develop in the physicochemical gradients established at the interfaces between water and solid substrates. These structures are composed primarily of phototrophic bacteria together with diverse microorganisms. They are frequently laminated due to variations of different parameters such as light, temperature, salinity, etc. These laminations have different colors as a result of growth of phototrophs with different pigment composition, and thus, different patterns of spectral utilization of the available light. Nevertheless, non-laminated microbial mats can be found, depending on environmental fluctuations.
In the last few years, two books (COHEN et al., 1984; COHEN \& ROSENBERG, 1989), and many articles have been published which extensively revise the structure, physiology, genetics and evolution of microbial mats (table 1).

Today, microbial mats are confined to a restricted range of habitats including hypersaline and coastal marine environments (BAULD, 1984; VAN GEMERDEN et al., 1989), hot springs (CASTENHOLZ, 1984; JORGENSEN \& NELSON, 1988) and alkaline lakes (BROCK, 1978). Microbial mats on deep-sea hydrothermal vents have also been studied. The emphasis on this particular community is of their chemosynthetic function (JANNASH, 1985; NELSON et al. 1989).

Marine microbial mats are inundated periodically because they are separated from the open sea by a shallow barrier: dunes (i.e. Baja California), salinas (Santa Pola, San Rafael, etc.), even the vegetation of mangrove trees [Matanzas, Cuba (R. Guerrero, unpublished; MARGULIS et al., 1986)].

Some microbial mats can be placed in strange places, like those found in the slopes of the caldera in the Kilauea crater (Hawaii). They are small irregulary-shaped patches, not more 
Table 1. Some important microbial mats of the world

\begin{tabular}{|c|c|c|}
\hline Location & Kind & Reference \\
\hline Yellowstone (Wyoming. USA) & Hot spring & CASTENHOLZ, 1984. \\
\hline New Zealand & Hot spring & CASTENHOLZ, 1976. \\
\hline Iceland & Hot spring & SCHWABE, 1960. \\
\hline Guaymas Basin (East Pacific) & Deep-sea hydrothermal vents. & BELKIN \& JANNASCH, 1989. \\
\hline Galapagos Rift (Ecuador) & Deep-sea hydrothermal vents. & JANNASCH, 1985. \\
\hline Solar Lake (Sinai) & Marine & KRUMBEIN et a l, 1977. \\
\hline Gulf of Aqaba (Sinai) & Marine & KRUMBEIN \& COHEN, 1974. \\
\hline Shark Bay and & & \\
\hline Spencer Gulf (Australia) & Marine & BAULD, 1984. \\
\hline $\begin{array}{l}\text { Laguna Figueroa } \\
\text { (Baja California, México) }\end{array}$ & Marine & HORODYSKI, et al. 1977. \\
\hline $\begin{array}{l}\text { Guerrero Negro } \\
\text { (Baja California, México) }\end{array}$ & Marine & JAVOR \& CASTENHOLZ, 1984 \\
\hline $\begin{array}{l}\text { Sippewisset } \\
\text { (Woods Hole, Mass., USA) }\end{array}$ & Marine & GIBSON et al., 1984. \\
\hline $\begin{array}{l}\text { Hamei Mazor } \\
\text { (Dead Sea, Israel) }\end{array}$ & Hypersaline sulfur spring & OREN, 1989. \\
\hline $\begin{array}{l}\text { Meijendel (dune area) } \\
\text { (The Netherlands) }\end{array}$ & Marine & WINDER et al., 1989. \\
\hline $\begin{array}{l}\text { Mellum Islands } \\
\text { (North Sea, Germany) }\end{array}$ & Marine & STAL et al., 1985. \\
\hline Orkney Islands (UK) & Sheltered beaches & HERBERT, 1985. \\
\hline Shackleford Banks (USA) & Marine & PAERL et al., 1989. \\
\hline Ebro Delta (Spain) & Marine & MIR et al., 1991. \\
\hline Canary Islands (Spain) & Marine & $\begin{array}{l}\text { MENDEZ \& VINUESA } \\
\text { (personal communication). }\end{array}$ \\
\hline Soda Lake (Nevada, USA) & Hypersaline lake & OREMLAND \& DES MARAIS, 1983. \\
\hline Hawaii (USA) & Marine & $\begin{array}{l}\text { GUERRERO } \\
\text { (personal communication) }\end{array}$ \\
\hline Cuba (Salina de Bido. Matanzas) & Marine (protected by mangroves) & MARGULIS et al., 1986. \\
\hline $\begin{array}{l}\text { Saltern of "Saline de Giraud" } \\
\text { (Camarge, France) }\end{array}$ & Hypersaline pond & CAUMETTE et al., 1988. \\
\hline
\end{tabular}


than 10 cin in diameter. They are scattered on the walls of the crater, some times tilted more than $70^{\circ}$ and presenting a different structure of those usually found in coastal zones. They are covered by a layer of black or dark-brown cyanobacteria (Mastigocladus laminosus is dominant), clearly defined purple and green layers (not more than $1 \mathrm{~mm}$ thick each one), and a basal layer of a yellowish, translucent gelatin, prohably constituted by polysaccharides. Thus, the black basal layer of anaerobic sulfate-reducers, which is almost universal in other microbial mats, is here absent. All sulfide and water is coming from the vapors steaming interinittently from fissures in the volcano walls, and therefore the cycling of sulfur compounds is not complete, reminding us of the earliest pre-ecosystems (unpublished data).

The development of microelectrodes to measure chemical gradients (REVSBECH \& JORGENSEN. 1985), micro-optic fibers for the study of spectral light distribution (PIERSON et al., 1987; JORGENSEN \& DES MARAIS, 1988). and electron microscopy techniques (STAL et al.. 1985; CAUMETTE, 1984; D'AMELIO et al. 1987), to better observe the structure and composition of these communities and the intra- and interspecific relationship have increased in the last few years our knowledge ofmicrobial mats.

From an evolutionary point of view, microbial mats are of great interest because they are considered modern homologs of some precambrian stromatolites. Also, microbial mats found in modern hot springs provide examples of precambrian communities. The high temperature of hot spring waters in combination with high $\mathrm{H}_{2} \mathrm{~S}$ concentrations or acidic conditions sometimes prevent the development of eukaryotes, facilitating the study of prokaryotic life.

Chemical fossils (organic compounds whose structures, in part, have survived in the fossil record) have been the starting point for many geochemical studies on modern inicrobial mats. The aim of these studies has been to identify the types of microorganisms present in ancient sediment by examining the types of biochemical markers (PALMISANO et al. 1988). Nevertheless. the complexity of these communities makes it difficult to determine the microbial origins of specific compounds found in the mats.

The role that mat-forming bacteria play on prokaryotic evolution (DES MARAIS, 1990), their role in laminated (STOLZ, 1990; KAZMERCZAK \& KEMPE, 1990; Mc NAMARA. 1990) and non-laminated microbial communities (CASTENHOLZ et al.. 1990), the description of new microorganisms (WAHLUND et al., 1991), and the elaboration of microcosms and models (GIANI et al., 1989) are other topics published recently.
Nevertheless, one of the questions of great interest that is not well understood is liow microorganisms living in microbial mats can survive under such extreme conditions as high light intensity, salinity, high temperatures and desiccation. Hyperscums, mucilages and polymer inclusions seem to play an important role here. Hyperscums have been described as crusted. buoyant, cyanobacterial mats often decimeters thick. in which the organisms are so densely packed that free water is not evident. ZOHARY (1985) postulated that the role of these dry crusts is similar to that of resting spores or cysts of other organisms, providing the innoculum for growth when conditions become favorable.

Also, adhesion by mucilage can serves as a survival mechanism at least for cyanobacteria. The mechanisms for attachment that have been found to operate in this group of microorganisms, involve a change of the cell surface properties (FALTON \& SHILO, 1984).

Less known is the role of biopolimers in the survival of microorganisms in microbial mats. The compounds that can be regarded as reserve material are usually polymers such as glycogen, poly-B-hydroxyalkanoates. cyanophycins and phycobiliproteins. Most of them are used by microorganisms as energy, carbon and nitrogen sources (JENSEN \& SICKO, 1971; LAWRY \& SIMON, 1982; GLAZER, 1981). The total amount of these storage compounds accumulated in the cell can be considerable . depending on the environmental conditions (ALLEN \& HUTCHISON, 1980; MASCASTELLÀ, 1991).

During the last fifteen years, our group has been studying freshwater stratified lakes, where phototrophic prokaryotes often form multilayered planktonic microbial communities (MPM) (GUERRERO et al., 1987; PEDRÓS-ALIÓ et al.. 1983). Microbial mats and MPM have been compared to ecosystems which depend on light as the primary energy source (GUERRERO \& MAS, 1989). Phototrophic organisms place themselves at different positions in these structures according to the vertical distribution of the environmental factors.

Also, we have studied the accumulation of poly-B-hydroxyalkanoates inclusions in Chromatiaceae in natural habitats (ESTEVE et al., 1990) and the characterization of predatory bacteria (GUERRERO eral.. 1986) and its dynamics controlling populations of Chromatiaceae in different karstic lakes (ESTEVE et al., 1992, and GAJU et al., in press).

Since 1987, we have been studying multilayered benihic microbial communities in the Ebro Delta and microbial mats froin different locations in Spain (GUERRERO \& DE WIT, 1992). 


\section{MICROBIAL MATS STUDIED IN THE IBERIAN PENINSULA}

A preliminary study of this kind of ecosystems has been made in Spain. Microbial mats can be found in different locations of the Iberian Peninsula and Canary Islands (fig. 1). They can be found in sediments of inland saline lakes (GUERRERO \& DE WIT, 1992) or in coastal areas close to salterns. Also, microbial mats have been located in other extreme environments such as sulfurous springs (i.e. Font de la Puda, Banyoles), and in hot springs (i.e. Fumarolas del Teide. Sta. Cruz de Tenerife).
The microbial mats we studied were located in the Mediterranean region of the Iberian Peninsula (fig. 1). All of them were situated close to saltern areas. The locations are "Salinas de San Rafael" (36046' N, 2036' O), "salinas de Cabo de Gata" (36 $46^{\prime}$ 'N, 2013' 0 ) in the province of Almería, "Salinas Bonmatí de Santa Pola" (38¹0' N, 0037' 0 ) in the province of Alicante, and the Ebro Delta, near Salinas de la Trinitat (40035' N, 040’ E), $50 \mathrm{~km}$ south of Tarragona. Samples of microbial mats from San Rafael, Cabo de Gata and Ebro Delta were collected in April 1989. Samples from Santa Pola were collected in November 1989.

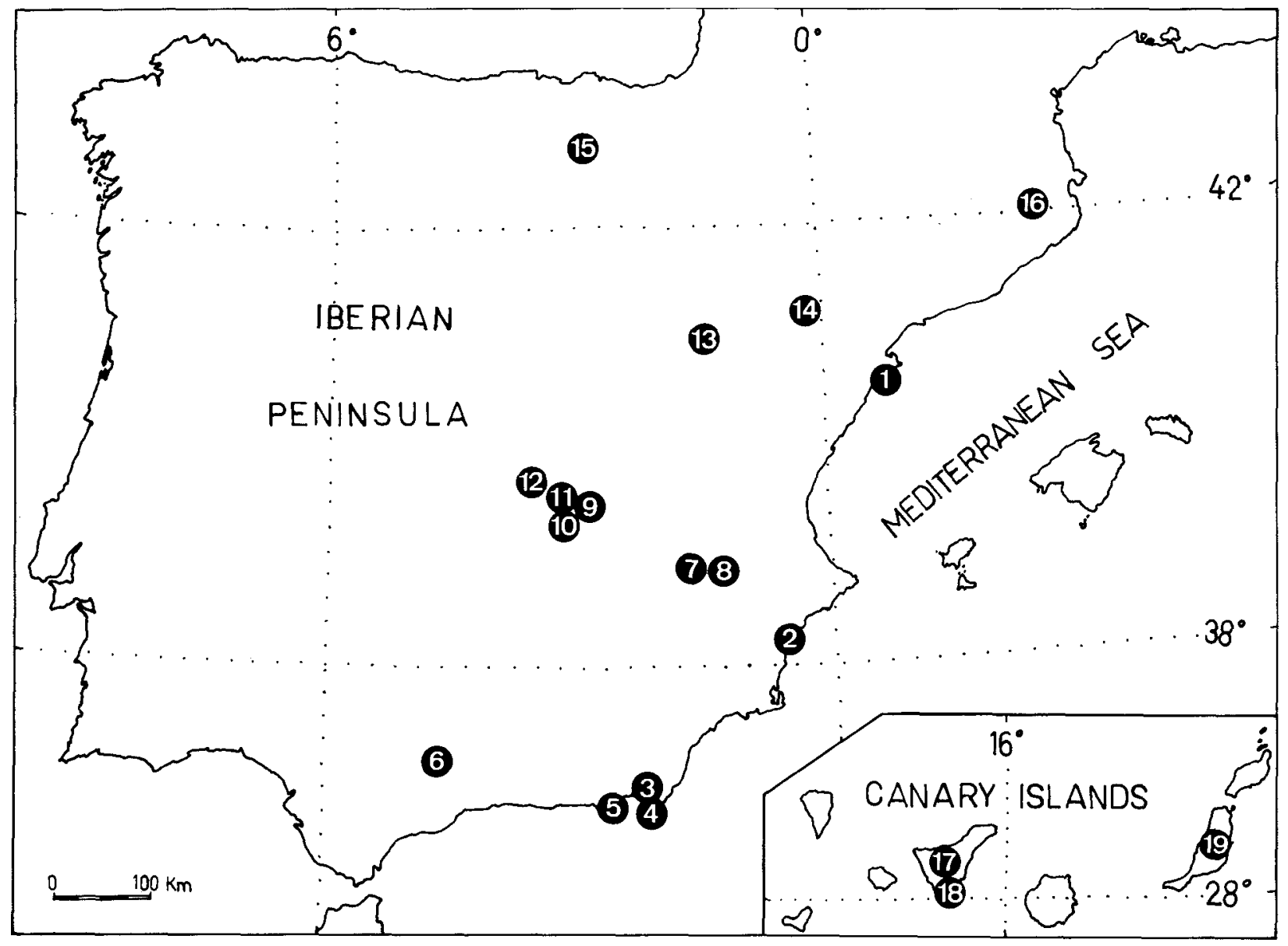

Figure 1. Geographical distribution of some microbial mats in the Iberian Peninsula and Canary Islands. $1^{\text {\% }}$. Ebro Delta (Tarrayona). Temporarily inundated sand flat. $2^{*}$. Salinas Bonmatí, Santa Pola (Alicante). $3 *$. Laguna de Cabo de Gata (Almería). 4*. Salinas de Cabo de Gata (Almería). $5^{*}$. Salinas de San Rafael (Almería). 61.. Fuente de Piedra (Málaga). Hypersaline lagoon. $7 \dagger$. Sanguijuela (Albacete). Endorheic lagoon. $8 \dagger$. Saladar (Albacete). Hypersaline lagoon 9†. Alcahozo (Ciudad Real). Hypersaline lagoon. 10†. Cerro Mesado (Ciudad Real). Hypersaline lagoon. $11 \uparrow$. Las Yeguas (Ciudad Real). Lagoon $\left(\mathrm{Mg}^{2+}\right.$ ) 121.. Laguna de Tirez (Toledo). Hypersaline lagoon. 131.. Gallocanta (Zaragoza). Endorheic and hypersaline lagoon. 14†. Chiprana (Zaragoza). Hýpersaline lagoon. 15†. Carravalseca (Alava). Endorheic and hypersaline lagoon. 16. Font de la Puda, Banyoles (Girona). Sulfurous spring. 17\#. Fumarolas del Teide (Santa Cruz de Tenerife). Hot spring. 18\#. El charco de la mareta, El Médano (Santa Cruz de Tenerife).Hypersaline pond. 19\#. Playas de Sotavento, Península de Jandía (Fuerieventura). Sand flat. ${ }^{*}$ This work. † C. Montes, 1990. \#Sebastián Méndez and Pablo Vinuesa from Universidad de la Laguna, personal communication. 

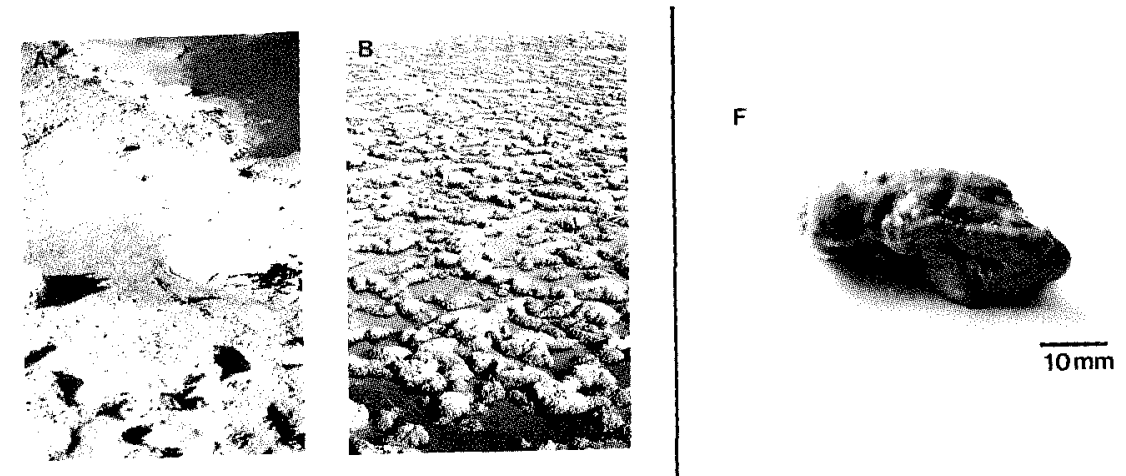

G
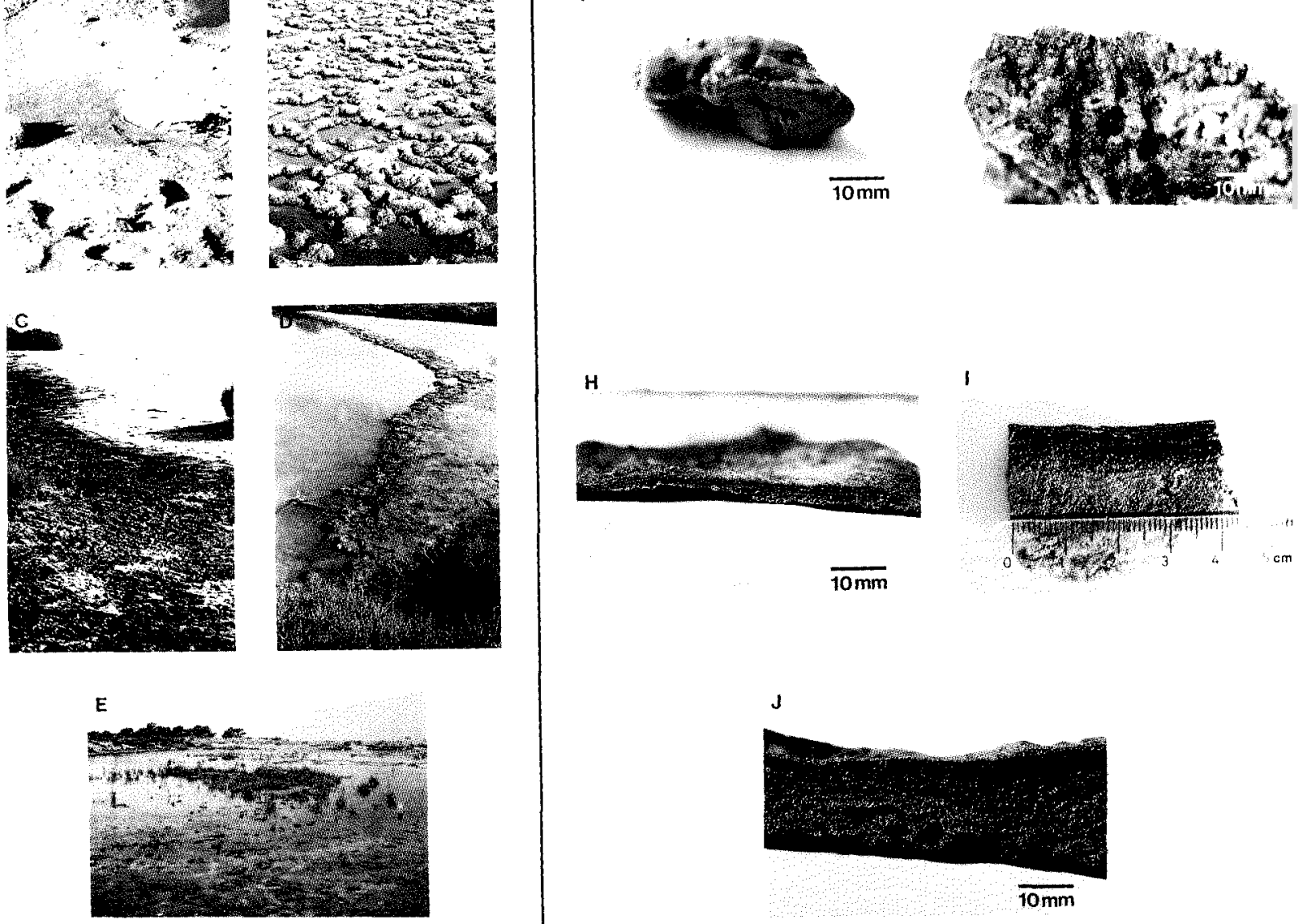

Figure 2. View of different sampling sites studied (A-E) aiid cross-secttons of microbial mats observed (E-J).

A) and F) Salinas de San Rafael, Almería; B) and G) Salinas de Cabo de Gata, Almería: C) aiid H) Laguna de Cabo de Gata, Almería; D) and I) Salinas Bonrnatí, Santa Pola, Alicante; E) and J) Sand flats of Ebro Delta, Tarragona.

Temperature, conductivity, and salinity of the water covering the microbial mats were measured in situ using a Yellow Springs Instrument S-C-T meter model 33. The pH was measured with a micro-pH 2001 Crison pH-meter.

Vertical stratification of the mats was studied by examining $1 \mathrm{~mm}$ thick vertical slices from top to bottom by phase contrast microscopy and scanning electron microscopy. Horizontal cross-sections of the mats were used to characterize more accurately the different individual layers. For pigment determination, the different colored layers were separated manually and extracted with methanol.

\section{Salinas de San Rafael (Almería)}

Two types of microbial mats were found in salinas San Rafael, on the shore of the ponds (fig. 2A). The water of the pond was brownish-red, presumably due to Halobacteriaceae. Artemia salina was also present. One of these microbial mats had developed on white sediment (fig. 2F). Three distinct colored layers could be distinguished. The uppermost layer was brownish-white in color, with gypsum precipitates on its surface. Diatoms were dominant in this layer. The second layer was green and coccoid cyanobacteria and some unidentified filamentous cyanobacteria about $3 \mu \mathrm{m}$ in diameter were observed. The third layer was dimly pink, and below these pigmented layers the sediment was white.

The second type of microbial mat found in salinas de San Rafael had two colored laminations. The upper layer was brown, and diatoms were the main phototrophic organisms present. The second layer was green, and coccoid cyanobacteria and some filamentous cyanobacteria could 

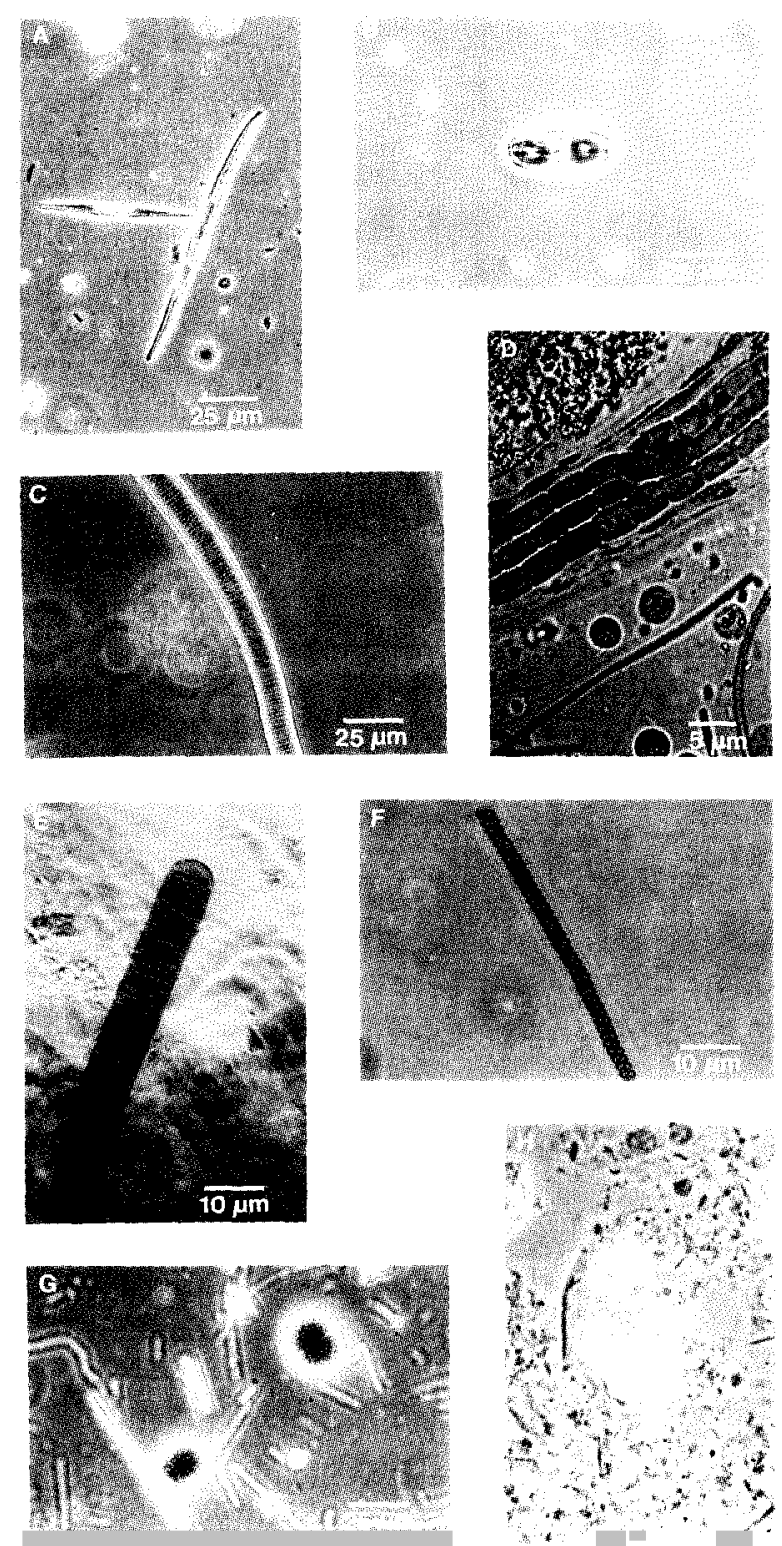

Figure 3. Photographic plate showing different organsms of the microbial mats studied. A) Gyrosigma sp., a diatom belonging to the family Naviculaceae: B) Amphora eggregia., a diatom belonging to the family Cymbellaceae: C) Lvnghva aestuarii filamentous cyanobacteria with pigmented sheath; D) Microcoleus chronoplastes, a sheathed filamentous cyanobacteria; E) Oscillatoria sp; F) Spirulina sp; G) Chroococ'us sp. a coccoid cyanobacteria belonging to the Gloeocapsa group: H) Chromatium sp., a purple sulfur bacteria.

be observed. Below this layer the sediment was black in color.

The absorption spectra of methanolic extracts of the different colored laminations showed that chlorophyll $a$ was the inain photosynthetic pigment in all colored layers, and little amounts of bacteriochlorophyll u could be detccted (fig. 5).

\section{Cabo de Gala (Almería)}

The structure of rnicrobial mats from "Salinas del Cabo de Gata" were similar to that of stromatolites. The high salinity, in conjunction with high levels of evaporation, has lead to the constitution of rigid gypsum crusts (fig. 2B). A vertical cross-section of these crusts (fig. $2 \mathrm{G}$ ) revealed a white surface layer with gypsum crystals, and below was a green layer dominated mainly by coccoid cyanobacteria (i.e. Syne-
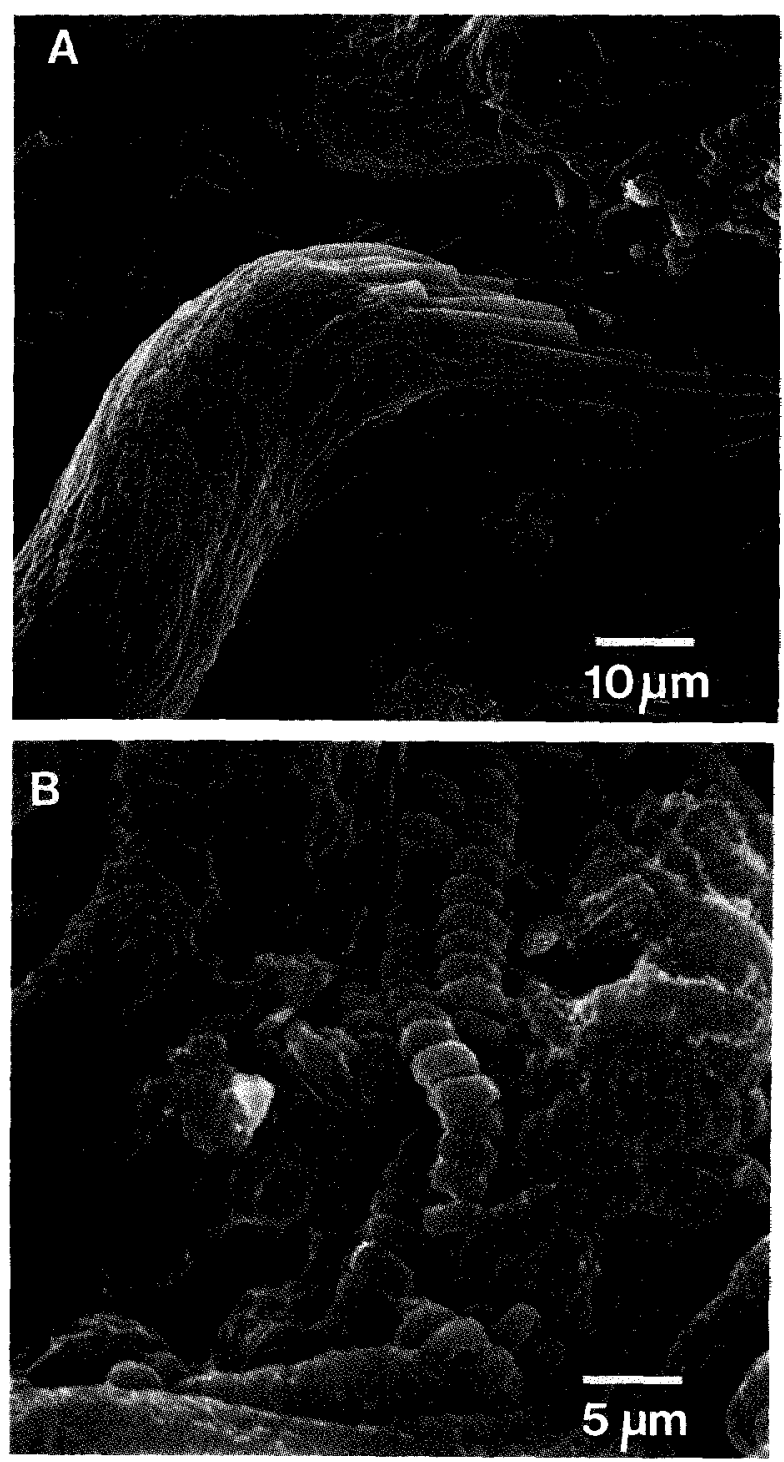

Figure 4. Scamning electron micrograph show me Al Whanders chtonoplastes and B) Spirulina sp. 


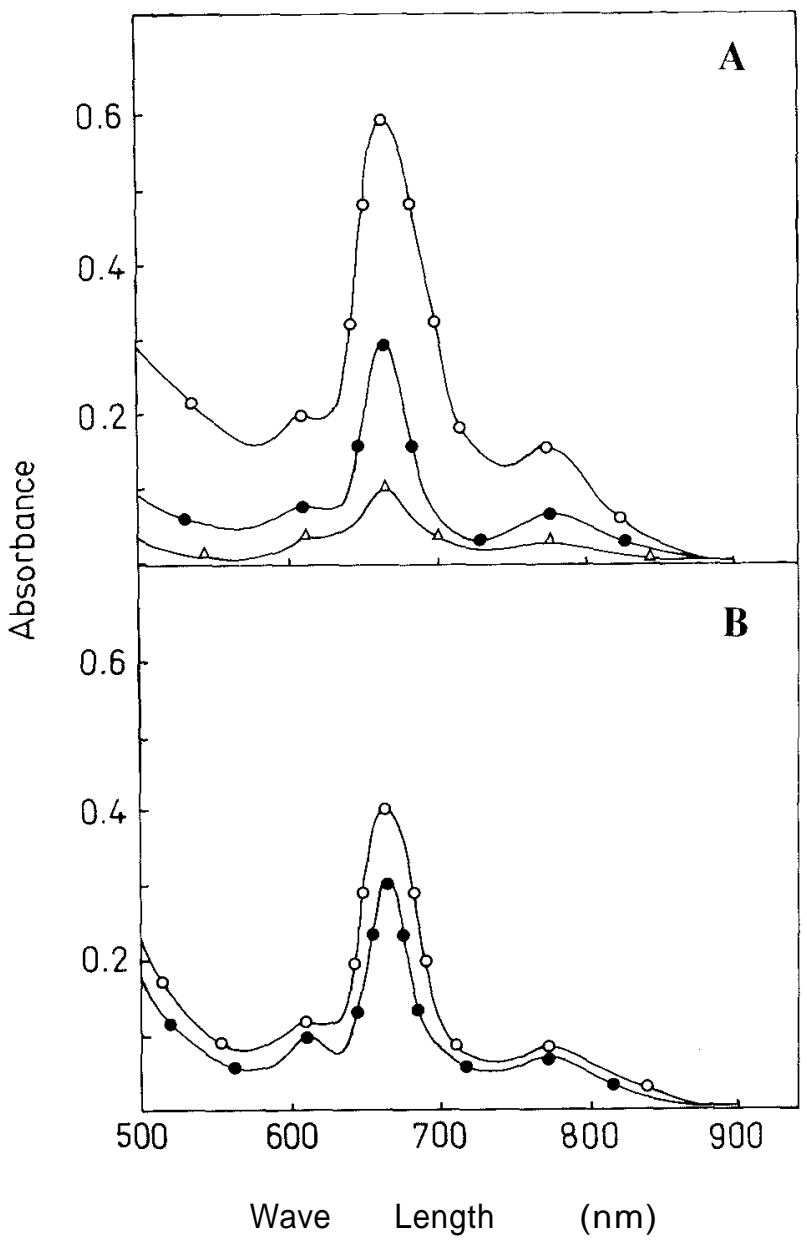

Figure 5. The red and intrased absorption spectra of methanolic extracts of differeiit pigmented laminations of microbial mats from Salinas San Rafael. A) Microbial mat developed on white sediment. B) Microbial mat developed on black sediment. ( -- .. Upper layer; _ $\mathrm{O}_{--}$green layer: $\Delta$-dimly pink layer).

chococcus sp.). Some filamentous cyanobacteria (i.e. Spirtlina sp. (figs. $3 F$ and $4 \mathrm{~B}$ )] was also observed. The methanolic extracts showed that chlorophyll $a$ was the main pigment present in this community (fig. 6B).

In "Cabo de Gata", we also found microbial mats on the shore of a lagoon (fig. 2C). These microbial mats were very thin and leathery in texture. Two pigmented layers were observed (fig. $2 \mathrm{H}$ ). The top layer was green, and the main phototrophic microorganism was Microcoleus sp. (fig. 3D and 4A). Some filaments of Oscillatoria sp. (fig. 3E) and Lynghya aestuarii (fig. 3C) were also present. The second layer was redish-orange, and phototrophic anoxygenic bacteria could be detected. Below this layer the sediment was black. Chlorophyll $a$ was the main pigment present in

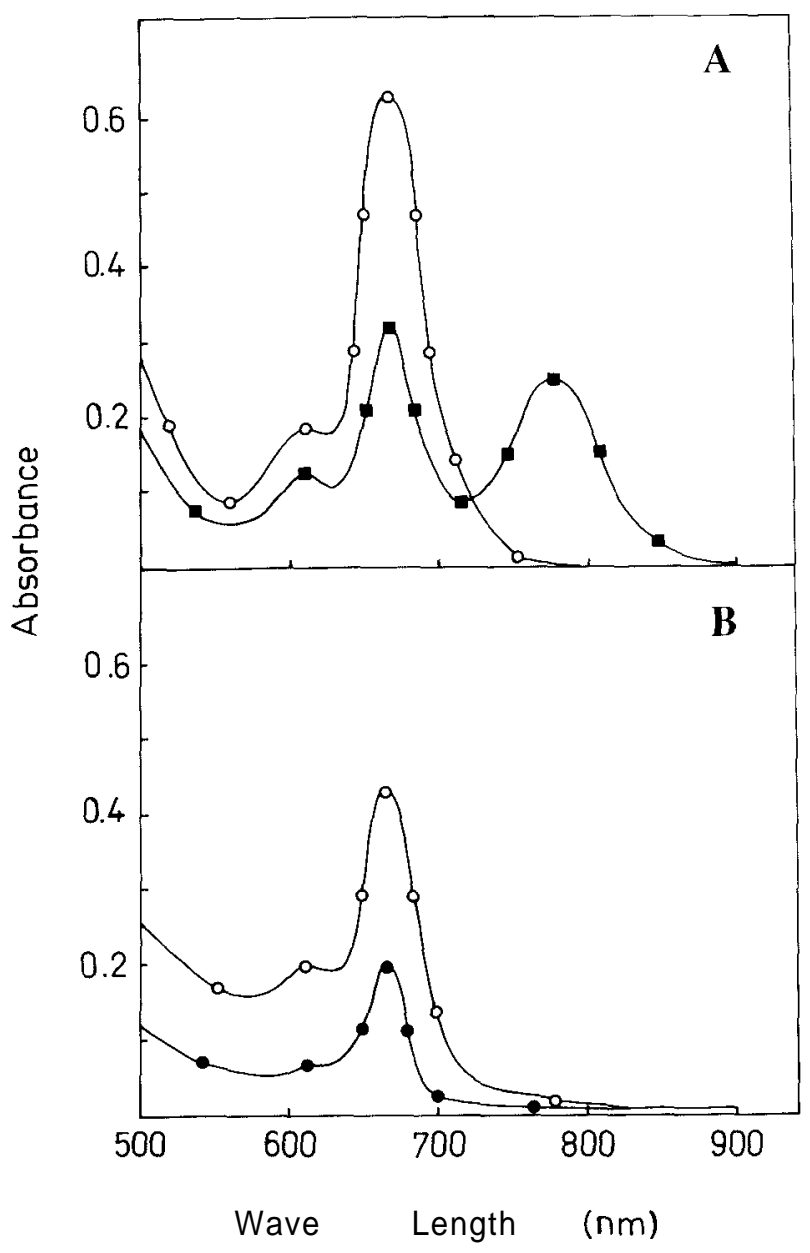

Figure 6. The red and infrared absorption spectra of methanolic extracts of differeiit pigmented laniinations of microbial mats from Cabo de Gata. A) Lagoon. B) Salinas. (- _ Upper layer; _ green layer; _ red layer).

the green layer, and bacteriochlorophyll $a$ was also detected in the second layer (fig. 6A).

\section{Santa Pola (Alicante)}

Very thin microbial mats were Found on the shore of a pond in "Salinas Bonmatí de Santa Pola" (fig. 2D). The water of the pond had a salinity of $50 \%$, the temperature was $17^{\circ} \mathrm{C}$, and the $\mathrm{pH}$ was 8.0.

These microbial mats had three different colored laminations (fig. 21). The upper layer was yellowish-brown, and the dominant organisms were diatoms (fig. 3A). The second layer was green in colour and the sheathed filamentous cyanobacteria, Microcoleus sp. (fig. 3D and 4A), was the main phototrophic bacteria present in this layer. The third 


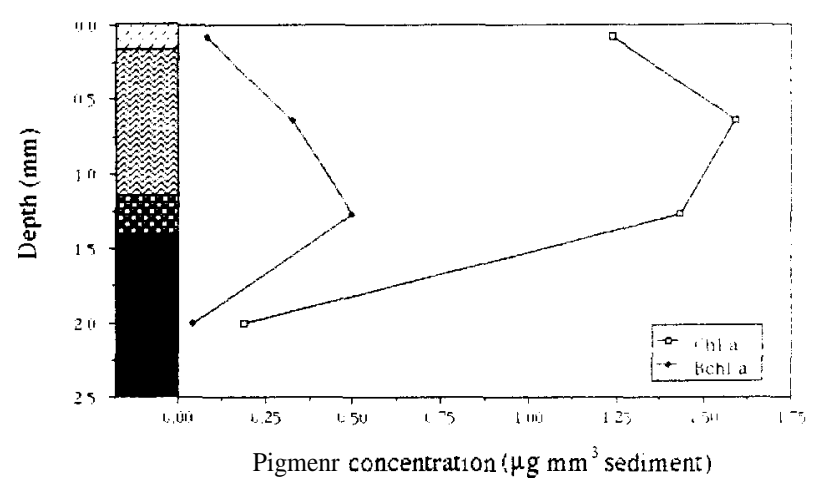

Figure 7. Pigment distribution with depth (methanol extract) of microbial mats from Santa Pola. The different layers were extracted and the concentration of predominant pigments (in $\mu \mathrm{g} . \mathrm{mm}^{-3}$ sediment) were determined for each lamination.

The distinct colored layers are designated by different symbols in the core diagram on the left ( $\square$ yellow-brown layer, $\square$ green layer, purple layer, black sediment). The pigment concentration from each layer is represented in the middle of the layer.

layer, purple in color, was mainly made up of small motile Chromatium sp. with sulfur globules inside. Below this last pigmented layer the sediment was black.

The distribution of predominant pigments was determined. Chlorophyll $a$ was the main photosynthetic pigment in all layers, reaching its maximum concentration $\left(1.6 \mu \mathrm{g} \cdot \mathrm{mm}^{-}\right.$ ${ }^{3}$ ) into the green layer at a depth of $0.7 \mathrm{~mm}$. Bacteriochlorophyll $a$ was also present, arriving at its maximum concentration $\left(0.5 \mu \mathrm{g} \mathrm{mm}^{-3}\right)$ at a depth of $1.26 \mathrm{~mm}$ (fig. 7).

\section{Ebro Delta (Tarragona)}

In the Ebro Delta, in a temporarily inundated sand flat (fig. 2E), we found very well developed microbial mats vertically stratified into three colored laminations (fig. $2 \mathrm{~J}$ ). In the top yellowish-brown layer, diatoms [i.e. Nitzschia, Navicula. Amphora (fig. 3B)] and coccoid cyanobacteria (fig. 3G) were dominant. The second layer, green in color, was composed mostly of Microcoleus chtonoplastes (fig. 3D and 4A) and a few filaments of Lyngbya aestuarii (fig. 3C) and coccoid cyanobacteria. The third layer, was purple and it was basically composed of anoxygenic phototrophic bacteria (fig. 3H), but some filaments of Microcoleus chtonoplastes and coccoid cyanobacteria were also present.

The principal pigment in both upper layers was chlorophyll $u$, which arrived at its maximum concentration $(0.5$ $\mu \mathrm{g} \cdot \mathrm{mm}^{-3}$ ) at a depth of $1.1 \mathrm{~mm}$ in the green layer. Bacteriochlorophyll $a$, predominantly found in anoxygenic phototrophic bacteria, increased with depth, reaching its maximum concentration $\left(0.35 \mu \mathrm{g} \cdot \mathrm{mm}^{-3}\right)$ at a depth of $2 \mathrm{~mm}$, in

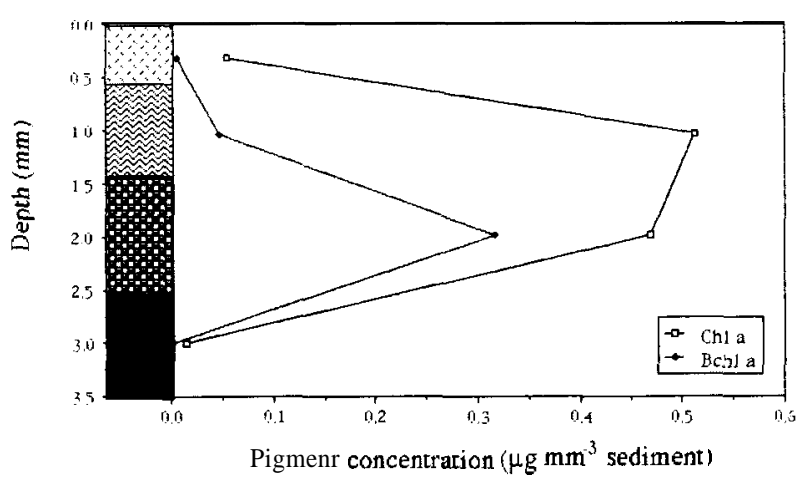

Figure 8. Pigment distribution with depth (methanol extract) of microbial mats from Ebro Delta. The different layers were extracted and the concentration of predominant pigments (in $\mu \mathrm{g} \cdot \mathrm{mm}^{-3}$ sediment) were determined for each lamination.

The distinct colored layers are designated by different symbols in the core diagram on the left ( $\square$ yellow-brown layer, $\square$ green layer, purple layer, black sediment). The pigment concentration from each layer is represented in the middle of the layer.

the purple layer (fig. 8). Several species of non phototrophic bacteria i.e. spirochetes and other unidentified small rods and cocci werc observed.

The vertical distribution of pigments from the Ebro Delta mats showed that microorganisms with chlorophyll $a$, like Microcoleus chtonoplastes, had a wide distribution throughout the mat, although purple sulfur bacteria like Chromatium sp., whose principal photosynthetic pigment is bacteriochlorophyll $a$. had a narrow distribution in the mat.

All mats studied were predominantly made up of cyanobacteria, with chlorophyll $a$ as the main photosynthetic pigment. But in well-developed mats with a purple layer (i.e. Santa Pola and Ebro Delta), bacteriochlorophyll $a$ was also present.

The highest concentration of main pigments analyzed was observed in Santa Pola mats, but in Ebro Delta mats the percentage of Bchl $a$ versus total chlorophyll (= Chl $a+$ Bchl $a$ ) was higher (41.2\%) than in Santa Pola mats (23.8 $\%)$, indicating that the contribution of anoxygenic phototrophic bacteria to total primary production is more relevant in Ebro Delta mats.

Pigment concentration was used as an estimation of phototrophic population biomass. Nevertheless, an increase in pigment concentration does not neccssarily indicate an increase in biomass. In stratified communities, microorganisms have to adapt to available light by increasing the amount of pigment content per cell to optimize the photosynthetic process (BROCH-DUE et al., 1978)

Most of the filamentous cyanobacteria observed in these microbial mats were sheathed, i.e. Microcoleus chtonoplas- 
tes and Lyngbya aestuarii. The sheaths play protective roles against dangers in the environment. An example of this function is the shielding ability of scytonemin, a yellowbrown pigment located in the sheath of several cyanobacteria such as Lyngbya sp., that protects them from high levels of solar radiation (GARCIA-PICHEL \& CASTENHOLZ, 1991). Lyngbya aestuarii located on the surface of the mats studied had more brownish coloration than the same organisms situated below.

Cyanobacterial mats which grow undisturbed for long periods may develop a regular lamination as the result of periodic changes in response to seasonal variations of the environment. Species composition, density of photosynthetic organisms, and levels of excretion of polysaccharides by bacteria change seasonally in response to changes in salinity, water cover, Iight intensity and temperature.

In hypersaline environments, the differences in composition of microorganisms depends on salinity levels. Coccoid cyanobacteria are the main microorganisms in environments where salinity is high, for example in Cabo de Gata salinas. Moreover, the diversity increases when salinity levels decrease. In this case, filamentous cyanobacteria, mainly Microcoleus sp., are the principal mat-building organisms, although coccoid cyanobacteria are also present.

This kind of microbial mats (Santa Pola and Ebro Delta mats) had three well distinguished colored laminations, and the dominant microorganisms were similar. Diatoms were present only in well established mats, building a new layer on the surface of these stratified communities.

In these photosynthetic communities, changes in structure can be observed not only seasonally but also in terms of location. For example, in Ebro Delta mats different mat development states were found in only a few meters of distance. Filamentous cyanobacteria such as Spirulina sp. were dominant in young mats; however, Microcoleus sp. was the main phototrophic microorganism in the green layer of well-developed microbial mats (MIR et al., 1991).

Although extensive work has been done on the subject of these kinds of communities, there is still little known about productivity, the role of polymer inclusions in oxygenic and anoxygenic phototrophic bacteria, and the inter-and intraspecific relationships among bacteria living on laminated structures,

The Hext studies in the Ebro Delta will provide more information about these interesting ecosystems developed in extreme environments.

\section{ACKNOWLEDGEMENTS}

We thank the Ebro Delta Natural Park Service (Generalitat de Catalunya) and Salines de la Trinitat for permission to collect samples. We gratefully acknowledge Dr. J. Mas-Gordi for critically reading the manuscript, J. Checa for his technical assistance and J. Bloomgarden for helping us in the English version. This work was supported by grants CICYT PB87-0500 to I. E. and BIO89-0591 and MAR91-0874 to R. G. We also thank the Autonomous University of Barcelona for a research grant to M. M-A. J. M. research was supported by grant PP88-39158752 from the Spanish Ministry of Education and Science ascribed to grant PB87-083 to C. Pedrós-Alió.

\section{REFERENCES}

ALLEN, M. M., \& F. HUTCHISON, 1980. Nitrogen limitation and recovery in the cyanobacterium Aphanocapsa 6308. Arch. Microbiol. 128: 1-7.

BAULD, J., 1984. Microbial mats in marginal marine environments : Shark bay, Western Australia, and Spencer Gulf, South Australia. In: Cohen, Y., Castenholz, R. W Halvorson, H. O (Eds.), Microbial Mats Stromatolites: 3958. Alan R. Liss, New York.

BELKIN, S., \& H. W. JANNASCH, 1989. Microbial mats at deep-sea hydrothermal vents: New observations In: Cohen, Y., \& E. Rosenberg (Eds.), Microbial mats. Physiological ecology of benthic microbial communities: 16-21. American Society for Microbiology Washington, D.C.

BROCH-DUE, M., J. ORMEROD \& F. STRAND, 1978. Effect of light intensity on vesicles formation in Chlorobium. Arch. Microbiol. 116: 269-274.

BROCK, T. D., 1978. The habitats. Thermophilic microorganisms and life at high temperatures, Springer-Verlag. New York.

CASTENHOLZ, R. W., J. BAULD \& B. B. JORGENSEN, 1990. Anoxygenic microbial mats of hot springs: thermophilic Chlorobium sp. FEMS Microbiol. Ecol. 74: 325-336.

CASTENHOLZ, R. W., 1976. The effect of sulfide on the blue green algae of hot springs. I. New Zealand and Iceland. J. Phycol. 12: 57-68.

CASTENHOLZ, R. W., 1984. Composition of hot spring microbial mats: a summary. In: Cohen, Y., Castenholz, R. W and Halvorson, H. O (Eds.). Microbial Mats Stromatolites: 101-119. Alan R. Liss, New York. 
CAUMETTE, P., 1984. Distribution and characterization of phototrophic bacteria isolated from the water of Bietri Bay (Ivory Coast). Cuw. J. Microbiol. 30: 273-284.

CAUMETTE, P., R. BAULAIGUE \& R. MATHERON, 1988. Characterization of Chromatium salexigens sp. nov., a halophilic Chromatiaceae isolated from Mediterranean salinas. System. Appl. Microhiol. 10: 284-292.

COHEN, Y., R. W. CASTENHOLZ \& H. O. HALVORSON (Eds), 1984. Microbial mats: Stromatolites. Alan R. Liss, Inc New York.

COHEN, Y. \& E. ROSENBERG (Eds), 1989. Microbial mats. Physiological ecology of benthic microbial communities. American Society for Microbiology, Washington, D.C.

D'AMELIO, E. D., Y. COHEN \& D. J. DES MARAIS, 1987. Association of a new type of gliding, filamentous, purple phototrophic bacterium inside bundles of Microcoleus chthonoplastes in hypersaline cyanobacterial mats. Arch Microbiol. 147: 213-220.

DES MARAIS, D.,1990. Microbial mats and the early evolution of life. TREE 5: 140-144.

ESTEVE, I.. E. MONTESINOS, J. G. MITCHELL \& R. GUERRERO, 1990. A quantitative ultrastructural study of Chromatium minus in the bacterial layer of lake Cisó (Spain). Arch. Microbiol. 153: 422-427.

ESTEVE, I., N. GAJU, J. MIR \& R. GUERRERO, 1992. Comparison techniques to determine the abundance of predatory bacteria attacking Chromatiaceae. FEMS Microbiol. Ecol. 86: 205-211.

FALTON, A. \& M. SHILO, 1984. Hydrophobicity as an adhesion mechanism of benthic cyanobacteria. Appl. Environ. Microhiol. 47: 135-143.

GAJU, N., I. ESTEVE \& R.GUERRERO. Distribution of predatory bacteria attacking Chromatiaceae in a sulfurous lake. Microb. Ecol. 24: (in press).

GARCIA-PICHEL, F.. R.W. CASTENHOLZ, 1991. Characterization and biological implications of scytonemin, a cyanobacterial sheath pigment. .1.Phycol. 27: 395-409.

GIANI, D., J. SEELER, L. GIANI \& W. E. KRUMBEIN. 1989. Microbial mats and physicochemistry in a saltern in the Bretagne (France) and in a laboratory scale saltern model. FEMS Microbiol. Ecol. 62: 151-162.

GIBSON, J., E. R. LEADBETTER \& H. B. JANNASCH, 1984. Great Sippewisset marsh: A summary of projects carried out by students in the microbial ecology course of the marine biological laboratory, Woods Hole, during summers 1972-1981. In: Cohen, Y., Castenholz, R. W and Halvorson, H. O., (Eds.), Microbial Muts Stromatolites: 95100. Alan R. Liss, New York.
GLAZER, A. N., 1981. Photosynthetic accessory proteins with bilin prosthetic groups: 51-96. In: M.D. Hatch and N.K. Boardman (Ed), Biochemistry of Plants, vol VIII : Photosynthesis. Academic Press, New York.

GUERRERO, M. C. \& DE WIT. R. 1992. Microbial mats in the inland saline lakes of Spain. Limnetica 8.

GUERRERO, R., C. PEDROS-ALIO. I. ESTEVE, J. MAS, D. CHASE \& L. MARGULIS, 1986. Predatory prokaryotes: Predation and primary consumption evolved in bacteria. Proc. Natl. Acad. Sci. 83: 2138-2142.

GUERRERO, R., C. PEDROS-ALIO, I. ESTEVE \& J. MAS. 1987. Cornmunities of phototrophic sulfur bacteria in lakes of the Spanish Mediterranean region. Acta Acad. Aho. 47: 125-151.

GUERRERO, R. \& J. MAS, 1989. Multilayered microbial communities in aquatic ecosystems: growth and loss factors. In: Cohen, Y. \& E. Rosenberg (Eds.), Microbial mats. Physiological ecology of benthic Mic robial communities: $37-$ 51. American Socicty for Microbiology Washington.

HERBERT, R. A. 1985. Development of mass blooms of photosynthetic bacteria on sheltered beaches in Scapa Flow, Orkney Islands, Proc. Roy. Soc. Edinburgh 87: 15-25.

HORODYSKI, R. J., B. BLOESSER \& S. J. VON DER HAAR, 1977. Laminated algal mats from a coastal lagoon, Laguna Mormona, Baja California, Mexico. J. Sedimrnt. Prt., 47: 680-696.

JANNASH, H. W., 1985. The chemosynthetic support of life and the microbial diversity at deep sea hydrothermal vents. Proc. R. Soc. Lond. Ser. B.: 225: 227-297.

JAVOR, B. J. \& R. W. CASTENHOLZ, 1984. Productivity studies of microbial mats, Laguna Guerrero Negro, México, pp. 149-170. In: Y. Cohen, R.W. Castenholz \& H.O. Halvorson (Ed), Microbial Mats: Stromatolites. Alan R. Liss, New York.

JENSEN, T. E. \& L. M. SICKO, 1971. Fine structure of poly-B-hydroxybutyrate acid granules in a blue-green alga, Chlorogloe a fritschii. J. Bacteriol. 106: 683-686.

JORGENSEN, B. B. \& D. J. DES MARAIS, 1988. Optical properties of benthic photosynthetic communities: fiber-optic studies of cyanobacterial mats. Limnol. Oceanogr. 33: 99-113.

JORGENSEN, B. B. \& D. C. NELSON, 1988. Bacterial zonation, photosynthesis, and spectral light distribution in hot spring microbial mats of Iceland. Microb. Ecol. 16: 133-147.

KAZMERCZAK, J. \& S. KEMPE, 1990. Modern cyanobacterial analogs of Paleozoic stromatoporoids. Science 250: 1244-1250.

KRUMBEIN. W. E. \& Y. COHEN, 1974. Klastische und evaporitische sedimentation in einem mesothermen mono- 
miktischen ufernahen See (Golf von Aqaba, Sinai). Geol. Rundsch. 63: 1035-1065.

KRUMBEIN, W. E., Y. COHEN \& M. SHILO, 1977. Solar lake (Sinai). 4. Stromatolitic cyanobacterial mats. Limnol. Oceanogr. 22: 635-655.

LAWRY, N. H. \& R. D. SIMON, 1982. The normal and induced occurrence of cyanophycin inclusion bodies in several blue-green algae. J. Phycol. 18: 391-399.

MARGULIS, L., L. LOPEZ-BALUJA, S. M. AWRAMIK \& D. SAGAN, 1986. Community living long before man: Fossil and living microbial mats and early life. The Science of rhe Total Environment 56: 379-397.

MAS-CASTELLÀ, J. 1991. Acumulación de poli- $\beta$ hidroxialcanoatos por bacterias. Distribución en la naturaleza y biotecnología. Ph. D. Thesis. University of Barcelona.

Mc NAMARA, K., 1990. Survivors from the primordial soup. New Scientist 8: 50-52.

MIR, J., M. MARTINEZ-ALONSO, I. ESTEVE \& R. GUERRERO, 1991. Vertical stratification and microbial assemblage of a microbial mat in the Ebro delta (Spain). FEMS Microbiol. Ecol. 86: 59-68.

MONTES, C. (coord.) 1990. Estudio de las zonas húmedas de la España peninsular. Inventario y Tipologia. Dirección General de Obras Hidráulicas, Ministerio de Obras Públicas y Urbanismo. Madrid.

NELSON, D. C., C. O. WIRSEN \& H. W. JANNASCH, 1989. Characterization of large, autotrophic Beggiatoa spp. abundant at hydrothermal vents of the Guayamas Basin. Appl. Environ. Microbiol. 55: 2909-2917.

OREMLAND, R.S., \& D.J. DES MARAIS, 1983. Distribution, abundance and carbon isotopic composition of gaseous hydrocarbons in Big Soda Lake, Nevada: an alkaline, meromictic lake. Geochim. Cosmochim. Acta 47: 2107-2114.

OREN, A., 1989. Photosynthetic and heterotrophic benthic bacterial communities of a hypersaline sulfur spring on the shore of the Dead Sea (Hamei Mazor). In: Cohen, Y., Castenholz, R. W \& Halvorson, H. O. (Eds.), Microbial Mats Str-omatolites: 64-76. Alan R. Liss, New York.

PAERL, H. W., B. M. BEBOUT \& L. E. PRUFERT, 1989. Naturally ocurring patterns of oxygenic photosynthesis and $\mathrm{N}_{2}$ fixation in a marine microbial mat: physiological and ecological ramifications. In: Cohen, Y., and E. Rosenberg (Eds.), Microbial mats. Physiological ecology of benthic Microbial communities: 326-341. American Society for Microbiology Washington, D.C
PALMISANO, A. C., S. E. CRONIN \& D. J. DES MARAIS, 1988. Analysis of lipophilic pigments from a phototrophic microbial mat community by high performance liquid chromatography. J. Microbiol Methods 8: 209-217.

PEDROS-ALIO, C.. E. MONTESINOS \& R. GUERRERO. 1983. Factors determining annual changes in bacterial photosynthetic pigments in holomictic lake Cisó, Spain. Appl. Environ. Microbiol. 46: 999-1006.

PIERSON, B., A. OESTERLE \& G. L. MURPHY, 1987. Pigments, light penetration, and photosynthetic activity in the multi-layered microbial mats of Great Sippewissett Salt Marsh, Massachusetts. FEMS Microbiol. Ecol. 45: 365-376.

REVSBECH, N. P., \& B. B. JORGENSEN, 1985. Microclectrodes: their use in microbial ecology. Adv. Microh. Ecol. 9: 293-352.

SCHWABE, G. H., 1960. Uber den thermobioten Kosmopoliten Mastigocladus laminosus Cohn. Blaugen und Lebenstraum. V. Schweeig. I. Hydrol. 22: 757-792.

STAL, L. J., H. VAN GEMERDEN \& W. E. KRUMBEIN, 1985. Structure and development of a benthic niarine microbial mat. FEMS Microbiol. Ecol. 31: 111-125.

STEEL, J. H., 1825. A description of the oolitic formation lately discovered in the county of Saratoga, and state of New York. Am. J. Sci. (ser. 1j, 9: 16-19.

STOLZ, J. F., 1990. Distribution of phototrophic microbes in the flat laminated microbial mat at Laguna Figueroa, Baja California. Mexico. Biosystems 23: 345-357.

VAN GEMERDEN, H., C. S. TUGHAN, R. DE WIT \& R. A. HERBERT, 1989. Laminated microbial ecosystems on sheltered beaches in Scapa Flow, Orkney Islands. FEMS Microbiol. Ecol. 62: 87-102.

WAHLUND, T. M., C. R. WOESE, R. W. CASTENHOLZ \& M. T. MADIGAN, 1991. A thermophilic green sulfur bacterium from New Zealand hot springs, Chlorobium tepidum sp. nov. Arch. Microbiol. 156(2 j: 81-90.

WINDER, B., J. PLUIS, L. REUS \& L. R. MUR, 1989. Characterization of a cyanobacterial algal crust in the coastal dunes of the Netherlands. In: Cohen, Y., and E. Rosenberg (Eds.), Microbial mata. Physiological ecology of benthic Microbial communities: 77-83. American Society for Microbiology, Washington, D.C.

ZOHARY, T., 1985. Hyperscums of the cyanobacterium Mycrocystis aeruginosa in a hypertrophic lake (Hartbeespoort Dam, South Africa ). I. Plankton Res. 7: 399-409. 